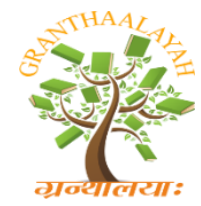

INTERNATIONAL JOURNAL OF RESEARCH GRANTHAALAYAH A knowledge Repository

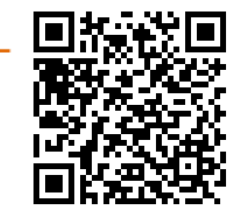

Management

\title{
FACTORS INFLUENCING THE CONSUMERS TOWARDS BUYING MARUTI CARS IN THOOTHUKUDI DISTRICT
}

\author{
R.AnanthaLaxmi ${ }^{* 1}$, A.Antony Selva Priya ${ }^{2}$ \\ ${ }^{*} 1,2$ Ph.D Research Scholars, PG and Research Department of Commerce, V.O.Chidambaram \\ College, Thoothukudi, India
}

DOI: https://doi.org/10.29121/granthaalayah.v5.i4(SE).2017.1948

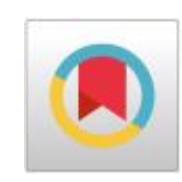

\begin{abstract}
With the explosion of the automobile industry, due to its globalization and liberalization, car manufacturers introduced much innovative and technological advancement in their models. Customers have started thinking to change over to the new models of cars, with related ease than before, to suit their changing life styles. Customer's perception of service and quality of product will determine the success of the product or service in the market. With better understanding of customer's perceptions, companies can determine the actions required to meet the customer's needs. They can identify their own strengths and weaknesses, where they stand in comparison to their competitors, chart out the path future progress and improvement. Customer satisfaction measurement helps to promote an increased focus on customer outcomes and stimulate improvements in the work practices and processes used within the company. This paper focuses to find out the factors influencing the consumers towards buying Maruti cars in Thoothukudi district. The sample size of the study is sixty respondents from Thoothukudi district. The study quantitatively analyses the consumers' buying behaviour, factors influencing the attitudes and behaviours of the consumers in buying Maruti car using primary data. Appropriate findings and suggestions are given in the paper.
\end{abstract}

Keywords: Buying Behavior; Maruti, Brand; Consumer.

Cite This Article: R.AnanthaLaxmi, and A.Antony Selva Priya. (2017). "FACTORS INFLUENCING THE CONSUMERS TOWARDS BUYING MARUTI CARS IN THOOTHUKUDI DISTRICT." International Journal of Research - Granthaalayah, 5(4)SE, 41-51. https://doi.org/10.29121/granthaalayah.v5.i4(SE).2017.1948.

\section{Introduction}

\subsection{Research Background}

The Indian Automobile Industry has got a tremendous market potential. With the growth of population and change in their pattern of life style as a result of urbanization, there has been a 
rapid increase in demand for Indian automobiles. The Indian Automobile Industry has flourished never before in the recent years (Vidyavathi, 2012).Life without vehicle is just beyond imagination these days. It is not only an indicator of national economy; but an individual's progress graph that can be measured on the grounds of the automobile vehicles used by him for day to day work and also for pleasures and treasures of happiness, prestige and style as well(ShriramShimpi,2012).

With the explosion of the automobile industry, due to globalization and liberalization, car manufacturers introduced much innovative and technological advancement in their models. Customers have started thinking to change over to the new models of cars, with related ease than before, to suit their changing life styles (JagathyRaj, 2012). The concept of "buying behaviour" is of prime importance in marketing and has evolved over the years. It is important to understand consumer buying behaviour as it plays a vital role in creating an impact on purchase of products. The human wants are unlimited and always expect more and more. Car Models are no exception to this behaviour. This lead to constant modifications of Car Models and its features and today we see a new model coming into the market practically every quarter.

\subsection{Statement of the Problem}

With the advent of economic liberalization and globalization, many of the transnational corporations have been shifting their production basis to India. It shows nearly more than five hundred manufacturing facilities have been established in India. Amongst all the sectors, automobile manufacturing sector recorded a considerable amount growth especially in India. Automobiles though considered as luxury once, now occupies a part of day-to-day life and has become a necessity. Thoothukudi, which is selected for the study, is one of the main growing markets for Automobile manufacturers. People who were not ready to spend their money on luxuries have now changed their attitude that yesterday's luxuries are today's necessities. To be a successful marketer it is absolutely essential to read the minds and perceptions of the prospective buyers of automobiles.

Only a limited number of attempts have been made to study the impact of brand preference factors on customer satisfaction. Based on these basic questions, the researcher has developed an interest to study the factors contributing brand preference of passenger cars and its impact on customer satisfaction level. Nowadays different brands of cars are available in the market, but the consumer prefers mainly the Maruti brand of car. Hence, the researcher has made an attempt to find the reasons for preferring Maruti brand of cars by the consumers.

\section{Objectives of the Study}

The objectives of the study are

1) To study the socio economic background of the consumer using four wheelers.

2) To understand the awareness and attitudes of the consumer in different brands of cars.

3) To study the factors influencing the consumers towards buying Maruti brand of cars.

4) To analyse the brand preference and importance given to Maruti cars. 


\section{Hypotheses}

1) Socio economic status of the consumer is not associated with the selecting a particular brand of cars.

2) Awareness and attitudes of the consumer is not associated with the purchasing of Maruti brand of cars.

3) The different factor influencing the purchase of car is not associated with the buying behaviour of the consumer.

4) In buying a car, the consumer does not give more importance to Maruti brand than other different brand of cars.

\section{Significance of the Study}

1) This helps to understand the information and understanding of the customer needs and expectations.

2) This study helps to gauge into the consumer's mind and understand the various consumption related aspects of consumers.

3) It also helps to learn about various internal and external influences, which impel the consumer to behave as they do.

\section{Scope of the Study}

The present study covers the area of Thoothukudi. It deals with the brand preference and its impact on the buying behaviour of consumers towards four wheelers. The period of this study is about one year i.e., August 2014 to September 2015.

\section{Methodology}

This study is conducted with the help of both primary and secondary data. The following research methodology is adopted in the study.

\section{Research Design}

Since the present study has its own predetermined objectives and methodology, it is both descriptive and analytical in nature. The study has made an attempt to explain the brand preference and its impact on the buying behaviour of consumers towards four wheelers.

\section{Sampling Design}

By adopting convenience sampling method, respondents were selected from various parts of Thoothukudi. The sample size of this study is 60 . A structured questionnaire was used to collect the relevant data. Questionnaires were distributed among the consumers in Thoothukudi District.

\section{Source of Data}

The present study is based on both primary data and secondary data. Primary data were collected through questionnaire. Secondary data were collected through books, websites, published articles, magazines and journals. 


\section{Collection of Data}

A well-structured questionnaire was used to collect primary data from the respondents. The questionnaire consists of four important parts. The first part covers the demographic profile of the respondents. The second part of the questionnaire includes the awareness and attitudes of the consumers towards different brands of cars. The third part includes the factor influencing consumers in buying Maruti brand of cars. The fourth part describes the brand preference and importance given to maruti brand of car.

\section{Pilot Study}

A pilot study was conducted among 20 respondents. Based on the feedback of the pilot study, necessary modifications, additions and deletions were carried out. The final draft was prepared to collect the data.

\section{Framework of Analysis}

The selection of statistical tools was based upon the nature of data used and objectives. The data were analysed by using the Statistical Package for the Social Science (SPSS) software package version 20. The applied statistical analyses are Inferential Statistics, Pie chart, Bar chart, ChiSquare Analysis, Regression and Factor Analysis.

\section{Results and Discussion}

This section shows the analysis and interpretation of data used for the study. All the detailed analysis related to the topic factors influencing the consumers towards buying Maruti cars in Thoothukudi district as discussed here.

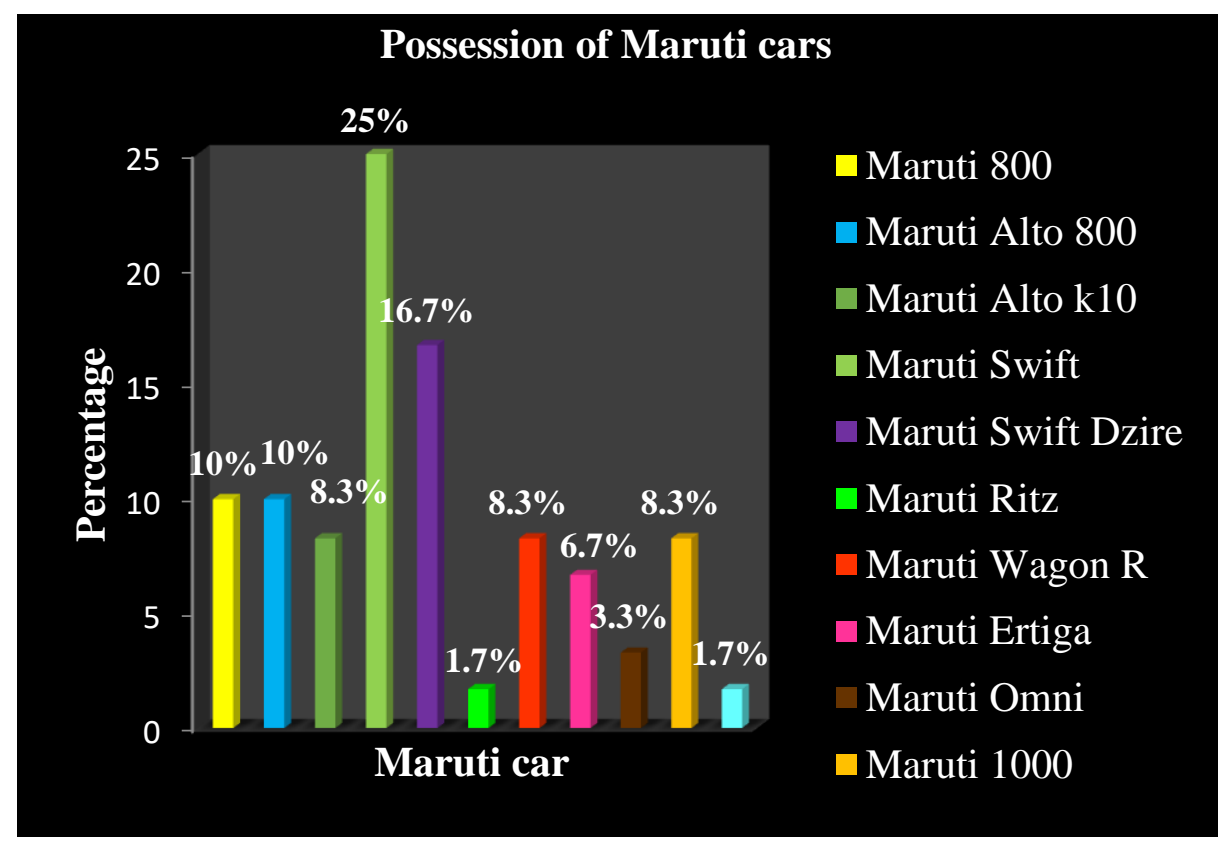

Figure 1: Possession of Maruti cars 
Figure 1 shows the variety of Maruti cars possessed by the customer. 10percent of the respondents possess Maruti 800 and Maruti Alto 800, 8.3percent possess Maruti Alto K10, 25percent possess Maruti Swift, 16.7percent possess Maruti Swift Dzire, 1.7 percent possess Maruti Ritz, 8.3percent respondents possess Maruti Wagon R, 6.7 percent possess Maruti Eritga, 3.3percent possess Maruti Omni, 8.3percent possess Maruti 1000 and 1.7per cent of the respondents possess Maruti Zenestilo. Majority of the consumers' possess Maruti Swift.

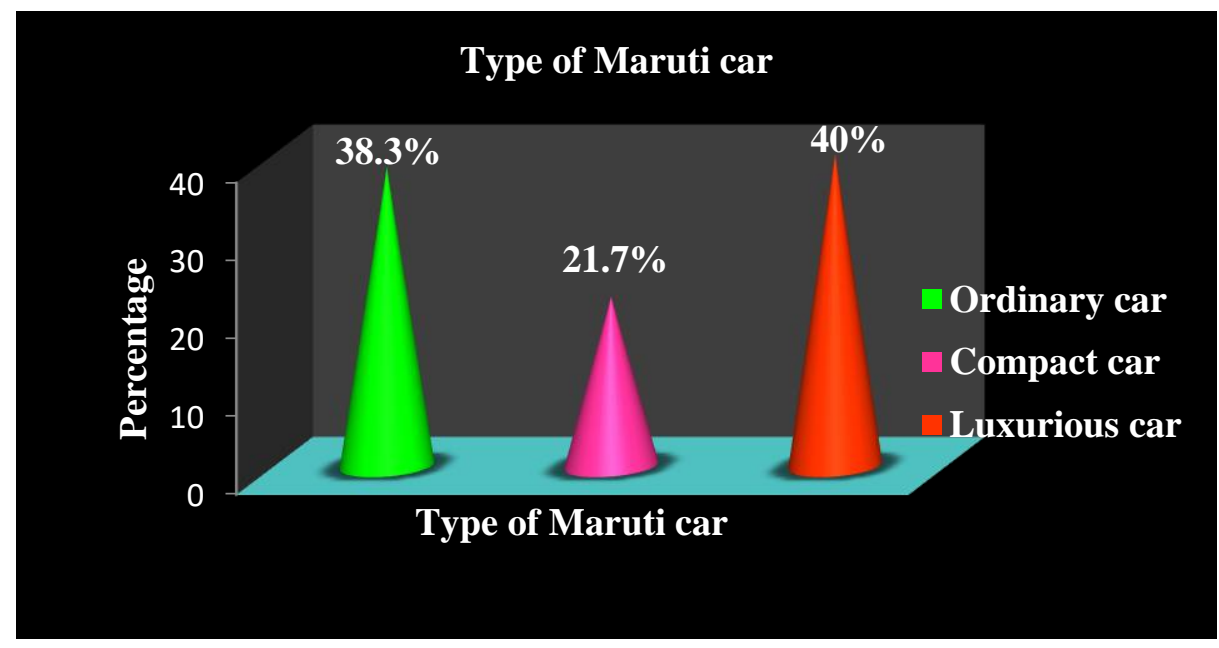

Figure 2: Type of Maruti car possessed

Figure 2 shows the type of Maruti car possessed by the consumers based on its comfort. Out of 60 respondents, 38.3per cent use ordinary car, 21.7 percent use compact car and 40percent use luxurious car. Hence, a greater part of the consumers use luxurious car.

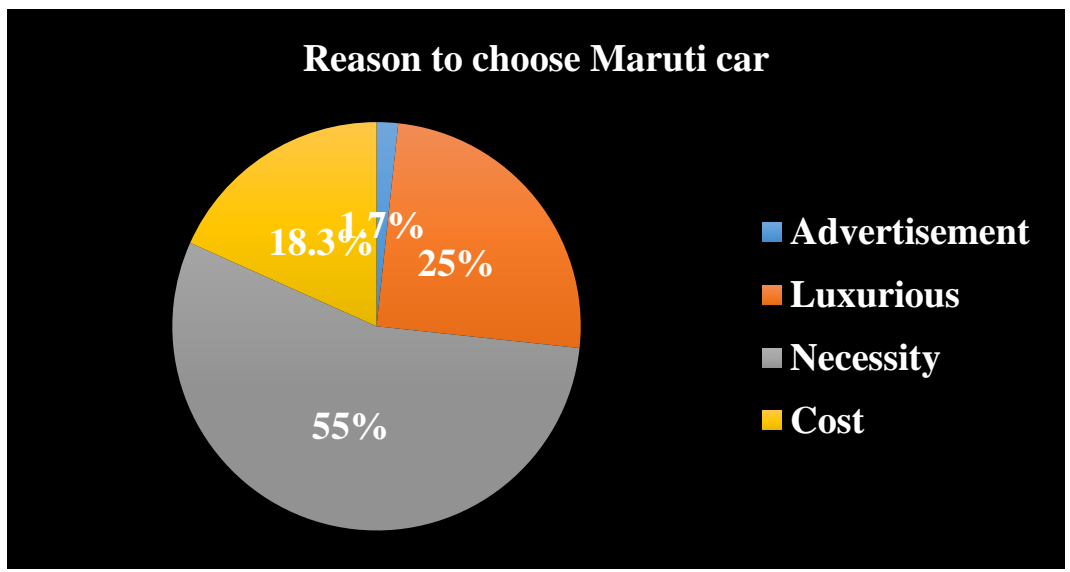

Figure 3: Reasons to choose Maruti car

Figure 3 shows the reasons to choose Maruti car by the consumers. 1.7per cent choose Maruti car by advertisement, 25per cent choose the Maruti car for luxury, 55per cent for necessity and 18.3per cent choose Maruti car by cost. Hence, majority of the respondents choose Maruti car for their necessity. 


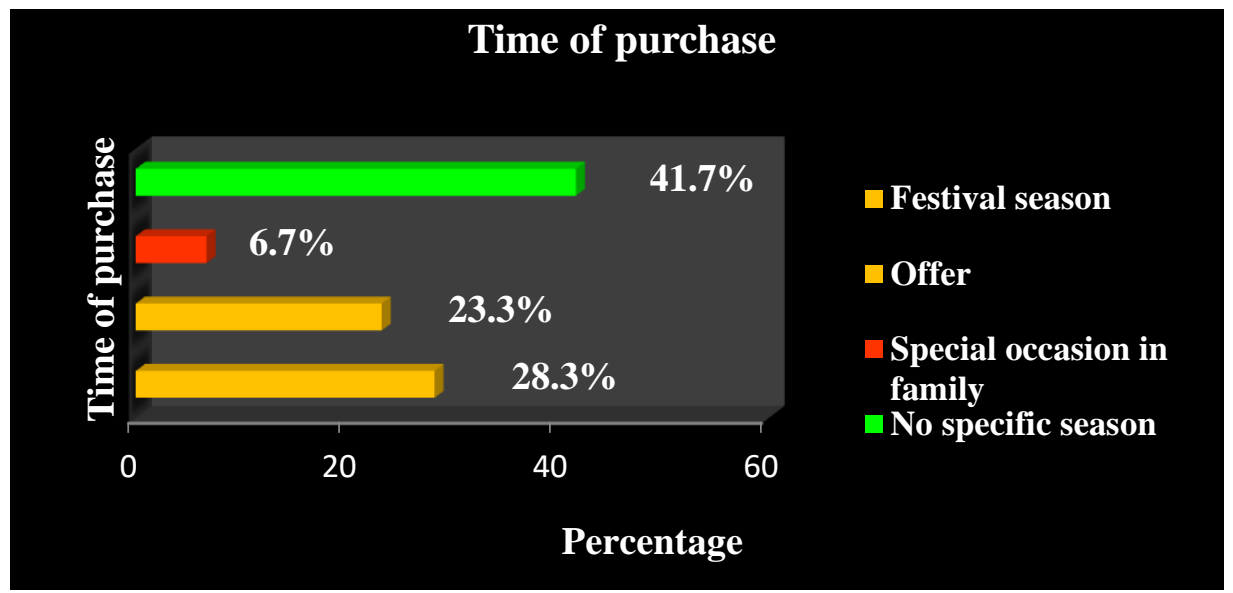

Figure 4: Time of purchasing the car

Figure 4 shows time of purchasing the car by the consumers. Out of 60 respondents, 41.7 percent purchase the car for no specific season, 28.3percent purchase the car during festival season, 23.3percent purchase the car during offer and 6.7percent purchase the car during any special occasion. Majority of consumers purchase the car for no specific season.

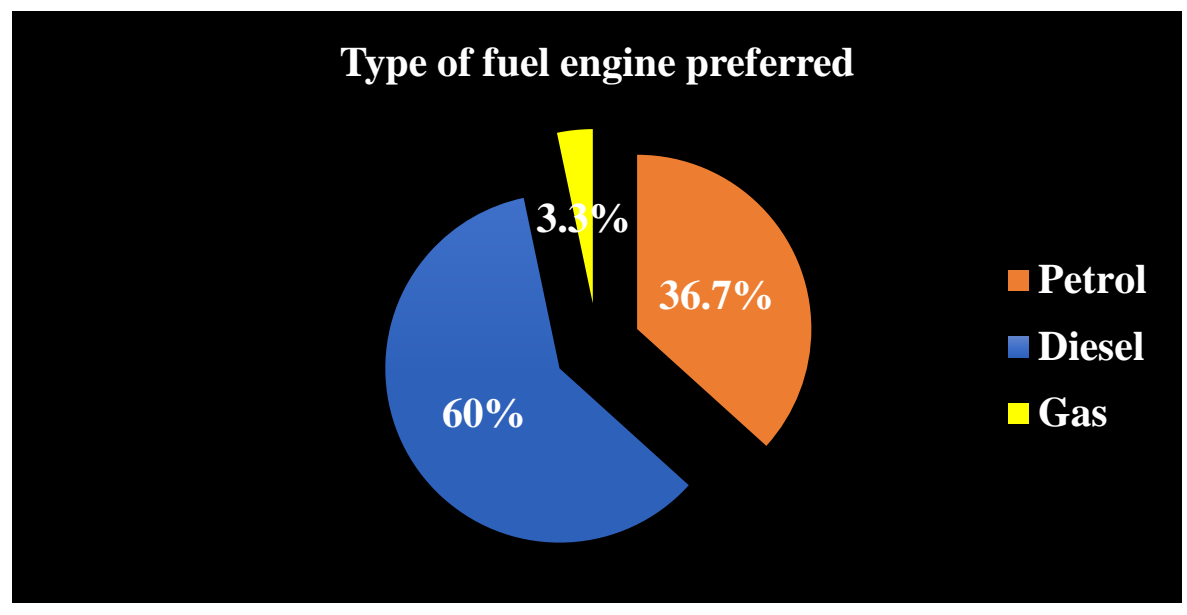

Figure 5: Type of fuel engine preferred

Figure 5 shows the preference of type of fuel engine by the consumers. Out of 60 respondents, 60per cent prefer diesel engine, 36.7per cent prefer petrol engine and remaining 3.3percent prefer gas engine. Majority of the consumers prefer diesel type of fuel engine. 


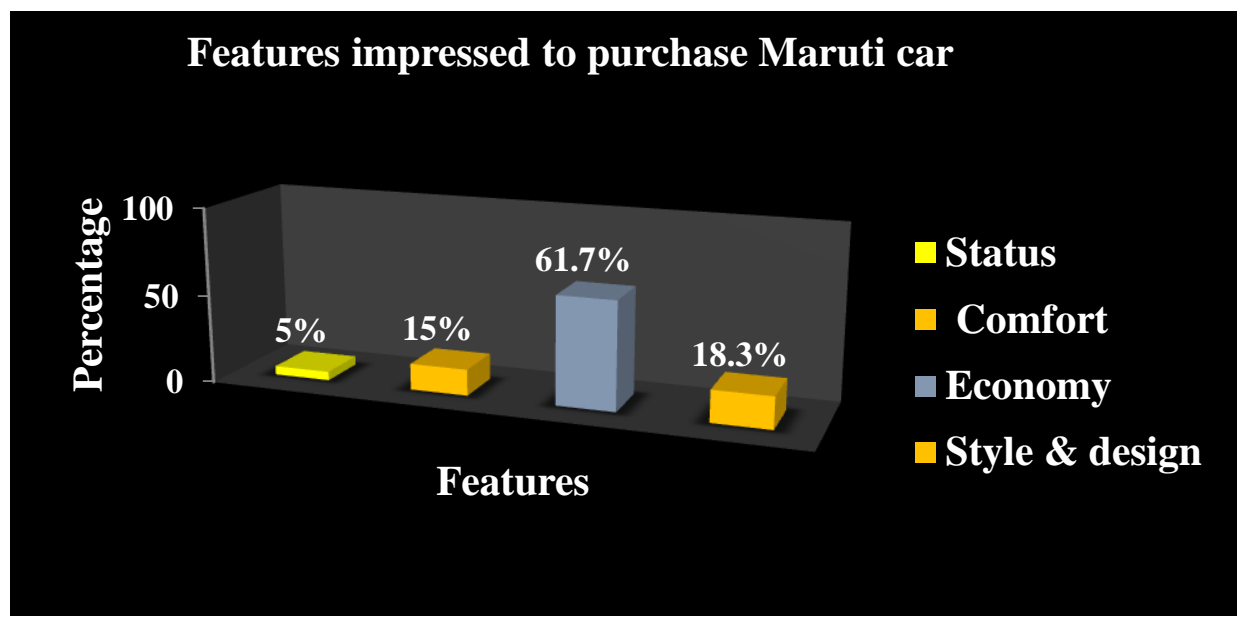

Figure 6: Features that impressed customers to purchase Maruti car

Figure 6 shows the features that impressed consumers to purchase Maruticar. Out of 60 respondents, 61.7per cent were impressed to buy the Maruti car for its economy, 15per cent were impressed by its comfort, 18.3per cent were impressed for its style and design, 5per cent were impressed for its status. Most of the respondents were impressed to purchase Maruti car for its economy.

Table 1: Reasons to choose Maruti car and Monthly Income of the consumers

\begin{tabular}{|l|l|l|l|l|l|l|}
\hline \multirow{2}{*}{ Monthly Income } & \multirow{2}{*}{ Factors } & \multicolumn{2}{|l|}{ Reason to choose Maruti car } & \multirow{2}{*}{ Total } \\
\cline { 2 - 7 } & & Advertisement & Luxurious & Necessity & Cost & \\
\hline \multirow{3}{*}{ Up to Rs.15,000 } & Respondents & 0 & 1 & 10 & 1 & 12 \\
\cline { 2 - 7 } & Income & $0.0 \%$ & $8.3 \%$ & $83.3 \%$ & $8.3 \%$ & $100.0 \%$ \\
\cline { 2 - 7 } & Reason & $0.0 \%$ & $6.7 \%$ & $30.3 \%$ & $9.1 \%$ & $20.0 \%$ \\
\hline \multirow{3}{*}{$\begin{array}{l}\text { Rs.15,000 } \\
\text { Rs.25,000 to }\end{array}$} & Respondents & 1 & 3 & 17 & 3 & 24 \\
\cline { 2 - 7 } & Income & $4.2 \%$ & $12.5 \%$ & $70.8 \%$ & $12.5 \%$ & $100.0 \%$ \\
\cline { 2 - 7 } $\begin{array}{l}\text { Rs.25,000 } \\
\text { Rs.35,000 }\end{array}$ & Reason & $100.0 \%$ & $20.0 \%$ & $51.5 \%$ & $27.3 \%$ & $40.0 \%$ \\
\hline \multirow{3}{*}{$\begin{array}{l}\text { Above Rs.35,000 } \\
\text { to }\end{array}$} & Respondents & 0 & 7 & 4 & 5 & 16 \\
\cline { 2 - 7 } & Income & $0.0 \%$ & $43.8 \%$ & $25.0 \%$ & $31.2 \%$ & $100.0 \%$ \\
\cline { 2 - 7 } & Reason & $0.0 \%$ & $46.7 \%$ & $12.1 \%$ & $45.5 \%$ & $26.7 \%$ \\
\hline & Respondents & 0 & 4 & 2 & 2 & 8 \\
\cline { 2 - 7 } & Income & $0.0 \%$ & $50.0 \%$ & $25.0 \%$ & $25.0 \%$ & $100.0 \%$ \\
\cline { 2 - 7 } & Reason & $0.0 \%$ & $26.7 \%$ & $6.1 \%$ & $18.2 \%$ & $13.3 \%$ \\
\cline { 2 - 7 } & Respondents & 1 & 15 & 33 & 11 & 60 \\
\cline { 2 - 7 } & Income & $1.7 \%$ & $25.0 \%$ & $55.0 \%$ & $18.3 \%$ & $100.0 \%$ \\
\cline { 2 - 7 } & Reason & $100.0 \%$ & $100.0 \%$ & $100.0 \%$ & $100.0 \%$ & $100.0 \%$ \\
\hline
\end{tabular}

Source: Primary data

Table 1 shows the relationship between the reasons to choose the Maruti car by the consumers and their monthly income. Out of 60 respondents, 40per cent of the consumers' monthly income is Rs.15,000 to Rs.25,000. In it, 70.8per cent choose Maruti car for necessity, 12.5per cent choose for luxury, 12.5per cent choose by cost and 4.2per cent choose by advertisement. Further, 26.7per cent of the consumers' income is Rs.25,000 to Rs.35,000. In it, 43.8per cent choose for 
luxury, 31.2per cent choose by cost and 25per cent choose for necessity. Next, 20per cent of the consumers' income is upto Rs.15,000. In it, 83.3per cent choose Maruti car for necessity, 8.3per cent choose for luxury, 8.3per cent choose by cost. Finally, 13.3per cent of the consumers' income is above Rs.35,000. In it, 50per cent choose Maruti car for luxury, 25per cent choose for necessity and 25 per cent choose by cost.

Table 2: Association between Reasons to choose Maruti car and Monthly Income of the consumers

*Significant at 5 per cent level

\begin{tabular}{|l|l|l|l|}
\hline Factor & Value & df & Sig.value \\
\hline Pearson Chi-Square & 18.106 & 9 & $0.034^{*}$ \\
\hline
\end{tabular}

Table 2 shows the association between reasons to choose Maruti car by consumers and their monthly income. As per rejection of null hypothesis $\mathrm{p}=0.034(\mathrm{p}<0.05)$, monthly income is associated with the reason to choose Maruti car. Therefore, monthly income of the consumers influences the reason to choose Maruti car. Hence, it is concluded that monthly income of the consumers affects the selection of Maruti car.

Table 3: Multiple regression on reasons for buying a car

\begin{tabular}{|c|c|c|c|c|c|}
\hline \multirow[t]{2}{*}{ Model } & \multicolumn{2}{|c|}{$\begin{array}{l}\text { Unstandardized } \\
\text { Coefficients }\end{array}$} & \multirow{2}{*}{$\begin{array}{l}\text { Standardized } \\
\text { Coefficients } \\
\text { Beta }\end{array}$} & \multirow[t]{2}{*}{ t value } & \multirow{2}{*}{$\begin{array}{l}\text { Sig. } \\
\text { value }\end{array}$} \\
\hline & $\mathrm{B}$ & Std. Error & & & \\
\hline (Constant) & .880 & .719 & & 1.223 & $.227 *$ \\
\hline Price & .205 & .099 & .232 & 2.061 & .044 \\
\hline Time saving & -.081 & .146 & -.064 & -.556 & .580 \\
\hline Family Travel & .511 & .093 & .583 & 5.506 & .000 \\
\hline Style and design & .136 & .088 & .171 & 1.543 & .129 \\
\hline \multicolumn{6}{|c|}{ Dependent Variable: Convenience and comfort } \\
\hline \multicolumn{6}{|c|}{ Independent variable: Style and design, Price, Family travel, Time saving } \\
\hline \multicolumn{6}{|c|}{ Multiple R: 0.643} \\
\hline \multicolumn{6}{|c|}{ R square: 0.414} \\
\hline \multicolumn{6}{|c|}{ Adjusted R square: 0.371} \\
\hline F statistics $(4,55): 9$ & 713 & & & & \\
\hline
\end{tabular}

*Significant at 5per cent level

Table 3 reveals the multiple regression used to access the ability of four control measures (Price, Time saving, Family travel and Style and design) that predicts its impact on the convenience and comfort provided by the car. $\mathrm{R}$ value (0.643) indicates the amount of variability explained by independent variables of Price, Time saving, Family travel and Style and design for 19per cent of variance in the dependent variable of convenience and comfort i.e., the remaining 81per cent is by some other unknown variable and the problem is not taken into account. Adjusted $\mathrm{R}^{2}$ indicates whether there any insignificant factor. It should always be less than or equal to $\mathrm{R}^{2}$. Here $\mathrm{R}^{2}$ $(0.414)$ and adjusted $R^{2}(0.371)$ are close to each other. This indicates a good model. $\mathrm{p}=0.227$ (above 0.05) shows there is no statistically significant difference and indicates all the independent variables Price, Time saving, Family travel and Style and design have no significance on convenience and comfort of the car. 
Factor Analysis on the factors influencing the brand preferences of consumers

Table 4: KMO and Bartlett's Test

\begin{tabular}{|l|l|l|}
\hline \multicolumn{2}{|l|}{ Kaiser-Meyer-Olkin Measure of Sampling Adequacy. } & 0.736 \\
\hline Bartlett's Test of Sphericity & Approx. Chi-Square & 236.819 \\
\cline { 2 - 3 } & Df & 36 \\
\cline { 2 - 3 } & Sig. & $0.000^{*}$ \\
\hline
\end{tabular}

*Significant at 5 per cent level

To verify whether the data set is suitable for factor analysis it has to be checked whether the KMO measure of sampling is 0.6 or above and whether the Bartlett's test of Sphericity value is significant (i.e., the significant value should be 0.05 or smaller). In this analysis, the KMO value is 0.736 and Bartlett's test is significant $(\mathrm{p}=0.000)$. Therefore, this factor analysis is appropriate. The component Eigen value should be 1 or more in the total variance. In this study only the first two components recorded Eigen value above 1(47.094 and 13.183). Overall, the model for 2 factors account for 60.277 percent which is relatively a good model.

Table 6: Rotation method Varimax with Kaiser Normalization

\begin{tabular}{|l|l|l|}
\hline \multirow{2}{*}{ Rotated Component Matrix } & \multicolumn{2}{|l|}{ Component } \\
\cline { 2 - 3 } & 1 & 2 \\
\hline Comfortable seating facility & .813 & .180 \\
\hline Easy to drive & .800 & \\
\hline After sale services provided by the dealer & .773 & .391 \\
\hline Attractive colour and appearance & .624 & .140 \\
\hline Pick up capacity & .616 & .494 \\
\hline Easy availability of spare parts at reasonable price & .500 & .493 \\
\hline Increase in price does not affect my brand preference & .117 & .862 \\
\hline Low maintenance cost & & .804 \\
\hline Fuel economy & .346 & .531 \\
\hline
\end{tabular}

The above table 6 indicates the factor loading of each variable in rotated component matrix which represents the variables under different factors. It shows that the 9 variables are reduced into 2 predominant factors. The predominant factors are: Factor 1 named as Appearance and comfort with variables Comfortable seating facility (0.813), Easy to drive (0.800), After sale services provided by the dealer(0.773), Attractive colour and appearance (0.624) and Pick up capacity(0.616).Factor 2 named as Cost efficiency with variables Easy availability of spare parts at reasonable price $(0.500)$, Increase in price does not affect my brand preference $(0.862)$, Low maintenance cost $(0.804)$ and Fuel economy(0.531).

\section{Findings of the Study}

1) Majority of the consumers (25per cent) possesses Maruti Swift. A major part of consumers (45per cent) use luxurious car. Majority of them (55per cent) choose Maruti car for their necessity and they (41.7per cent) purchase the car for no specific season. Majority of the consumers (60per cent) prefer diesel type of fuel engine. Most of the 
respondents (61per cent) were impressed to purchase Maruti car for its economy. Monthly income of the respondents affects the selection of Maruti car.

2) The independent variables Price, Time saving, Family travel and Style and design have no significance on convenience and comfort of the car.

3) Factor analysis shows that the factors influencing the brand preferences of consumers can be grouped into two predominant factors Appearance and comfort and Cost efficiency. Customers switch over to competing brands and models, if their chosen model is readily available in the market. The awareness, intelligence and availability of popular models in the market are based on these specific requirement needs of the customers.

\section{Suggestions and Conclusion}

In this digital and fast growing world, car is no longer a luxury. Yesterday's luxuries are today's necessities. The growth in the population of India and the increasing number of middle class consumers has attracted the attention of car manufacturers and marketers. In this research, the researcher concludes that the overall satisfaction of the customers regarding all car companies is at good. There are certain product attributes which are identified in the study as influencing the purchase decision and satisfying the consumers. Income, age, gender are very important factors that influence the purchase decision. Due to easy availability of the loans and financing options most of the people are opting for them to buy their car. Most of the people purchase the vehicles for their own purpose. Dealers try to give their best services and try to retain the customer as there are other dealers competing with each other for the same brand. Customers seem to find no major difference among the car brands in a segment as far as performance is concerned. The brand perception is dependent mostly on the peripheral cues depending upon the nature and quality of the service provided along with the pricing, maintenance, availability of spare parts and related issues. Maruti cars cover all the aspects and expectation of the consumers.

\section{References}

[1] BalakrishnanMenon, and Jagathy Raj V.P., (2012).Dominant mean percentage score factors of the consumer purchase behaviour of passenger cars. International Journal of Research in IT \& Management, Volume 2, Issue.5,PP,15.

[2] BalaSubrahmanya, M.H., (2007), Development of Strategies for Indian SMEs: Promoting Linkages with Global Transnational Corporations, Management Research News, Vol. 30, No. 10, pp, 762-774.

[3] FarhatAnjum., (2013).Buying Behavior and Customer Satisfaction of Hyundai Cars in Hyderabad City. International Conference on Technology and Business Management, PP, 32.

[4] Golden, S. A. R. (2017). Recent Research In Social Science \& Humanities.

[5] Golden, S. A. R., \& Regi, S. B. (2013). Mobile Commerce in Modern Business Era. International Journal of Current Research and Academic Review, 1(4), 96-102.

[6] Nikhil Monga., (2012).Car market and buying behavior- A study of consumer Perception. International Journal of Research in Management, Economics and Commerce, Volume2, Issue 2.PP, 45.

[7] Regi, S. B., \& Golden, S. A. R. (2014). A DESCRIPTIVE STUDY ON THE ROLE OF CONSUMER PSYCHOLOGY AND BEHAVIOUR IN PRODUCT PURCHASING”. Indian Streams Research Journal, 3(12), 1-6.

[8] Regi, S. B., Golden, S. A. R., \& Franco, C. E. (2014). A DESCRIPTIVE STUDY ON THE PROSPECTS OF E-COMMERCE IN INDIA. Golden Research Thoughts, 3(9), 1-7. 
[9] ShriramShimpi.,(2012).A Study On Consumer Buying Behaviour For Used Cars In Pune City. National Monthly Refereed Journal Of Research In Commerce \& Management, Volume No.1, Issue No.9,PP,29.

[10] UNCTAD,(2008)World Investment Report 2008, United Nations Conference Report on Trade and Development, Geneva.

[11] Vidyavathi,K., (2012). Consumer lifestyle influence of consumer behaviour with reference to automobile industry in Chennai.International Journal of Multidisciplinary Research Vol.2, Issue No.4,PP,38.

[12] Vidyavathi,K.,(2012).Consumer lifestyle influence of consumer behaviour with reference to automobile industry in Chennai.International Journal of Multidisciplinary Research,Vol.2,Issue 4,PP,39. 